\title{
Society pages
}

\section{Wildlife Photographer of the Year Competition 1986}

The quality of the entries in the 1986 Wildlife Photographer of the Year Competition beat that of all previous years. according to Bruce Coleman. chairman of the judges for the world's largest international wildlife photographic competition. Thousands of entries poured in for the 14 categories from all over the world. A small selection of the winning photographs is reproduced on this and the following two pages, but the complete collection is being exhibited at the British Museum (Natural History) in London until 1 February 1987.

At a ceremony on 27 November 1986, winners of each category received their prizes from wellknown people in the world of natural history. including David Attenborough, David Bellamy. Tony Soper and Julian Pettifer. Sir Peter Scott presented the overall prizewinner. Rajesh Bedi. Wildlife Photographer of the Year 1986, with the Prudential Assurance Award-a bronze model of a scarlet ibis and a holiday for two in Tasmania. courtesy of British Airways, Ansett Airlines and the Tasmanian Department of Tourism. All adult prizewinners received a year's membership of the FFPS.

The competition and exhibition were sponsored by Prudential Assurance, in association with $B B C$ WILDLIFE magazine, the FFPS and the Natural History Museum, supported by British Airways and Ilford Ltd.

Details of the 1987 competition are available from BBC WILDLIFE magazine, Broadcasting House, Whiteladies Road, Bristol BS8 2LR, UK.

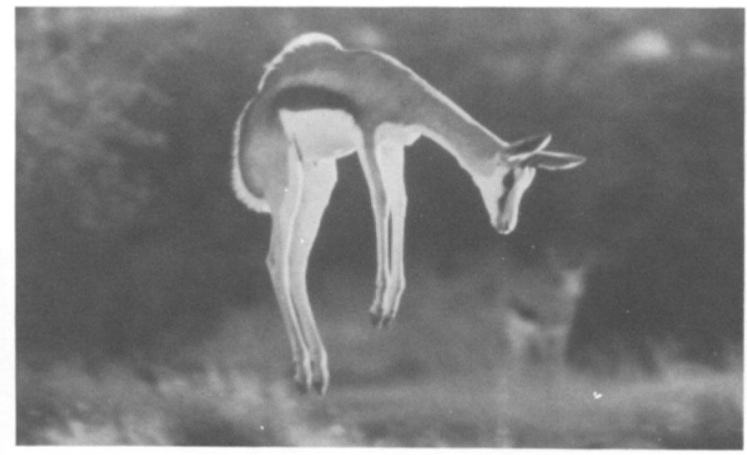

Springbok 'pronking', by Barrie Wilkins of South Africa. First prize, 'Wildlife in Action'.

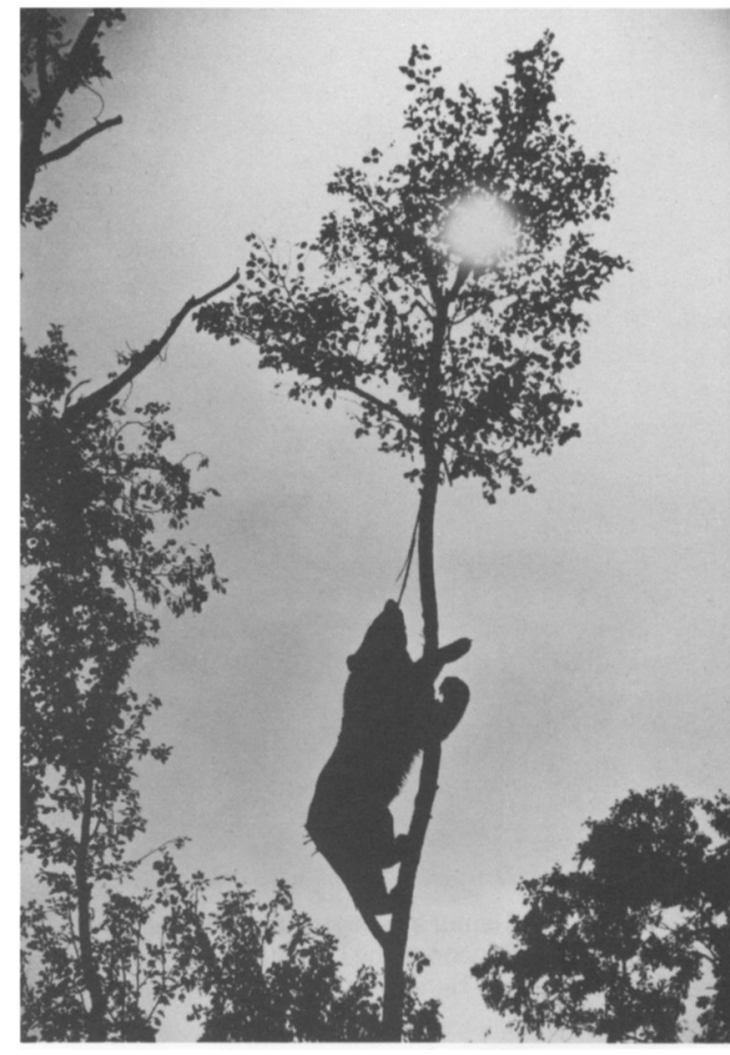

Himalayan bear stripping bark from a tree, by Rajesh Bedi of India, winner of the Prudential Assurance Award.

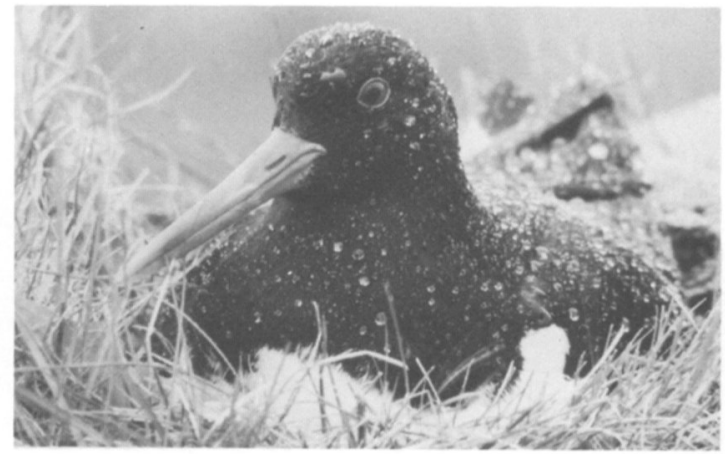

Oystercatcher by Mike Wilkes of the UK. First prize, 'Animal Portraits'. 


\section{Society pages}

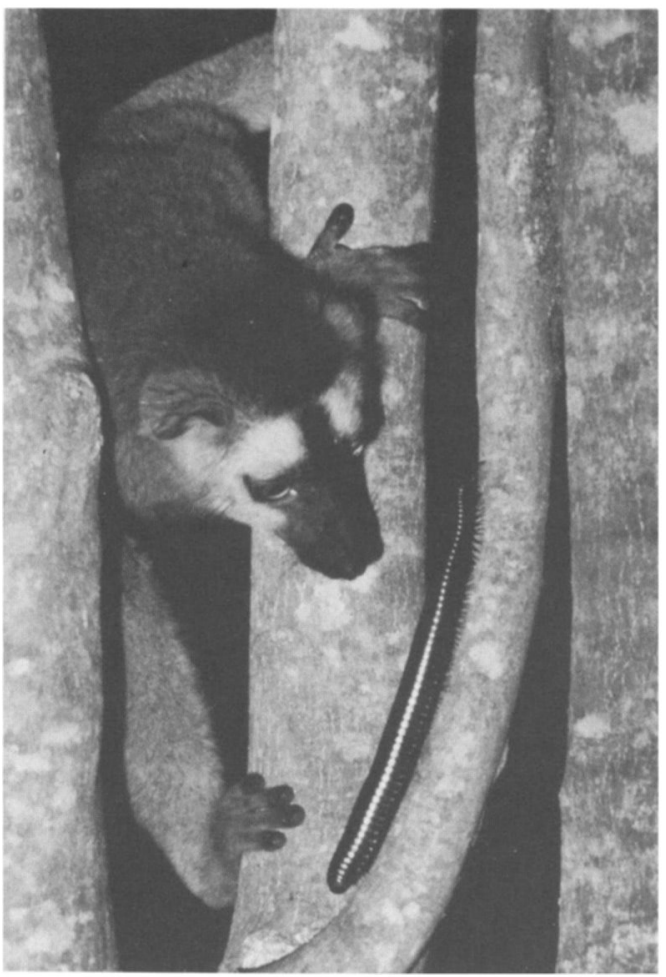

Red-fronted lemur investigating a millipede, by Mark Pidgeon of the UK. Runner-up, 'Animal Behaviour-Mammals'.

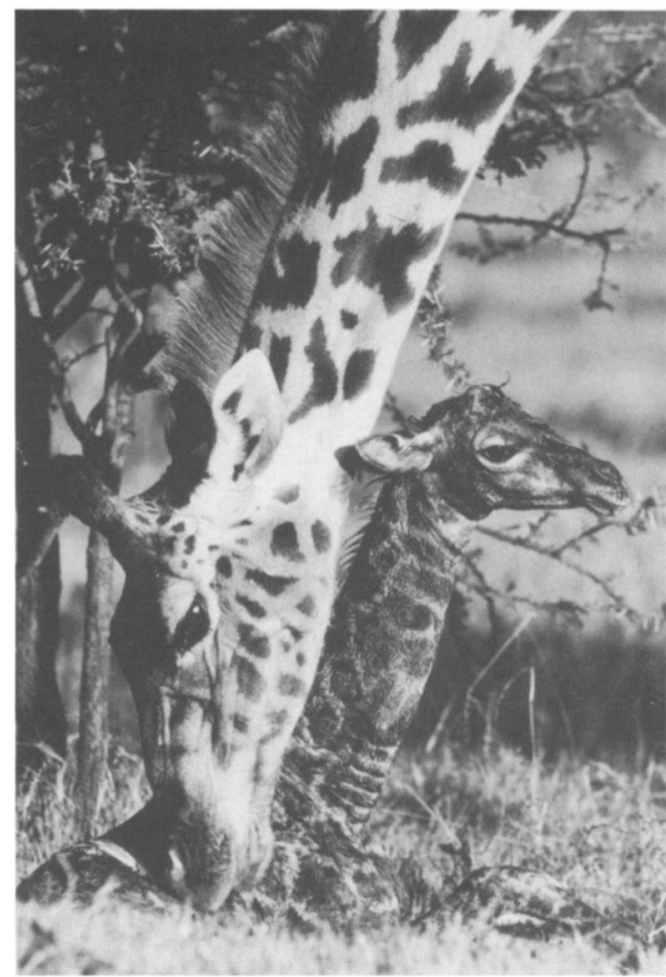

Giraffe with new-born calf, by donathan Scott of the UK. First Prize, 'Animal Behaviour-Mammals'.

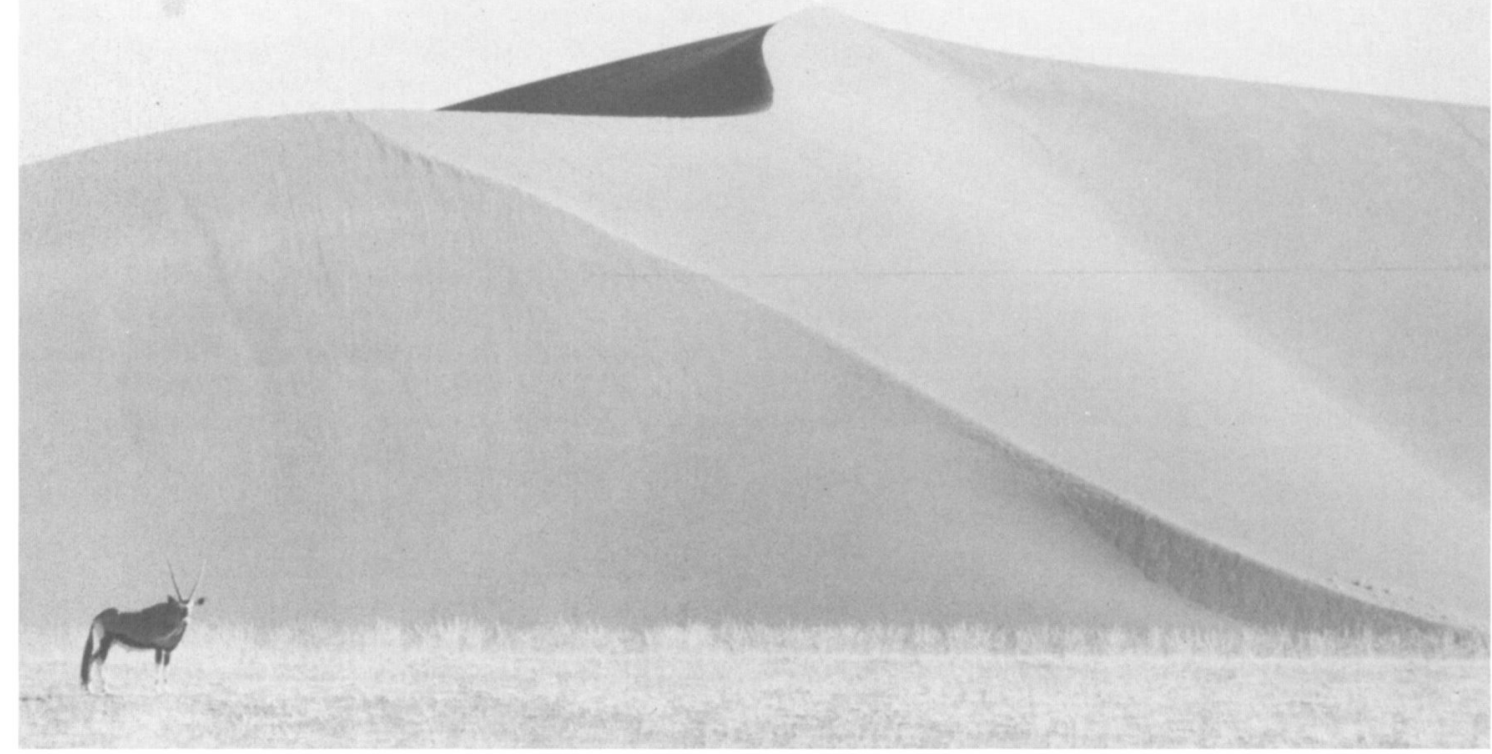

Gemsbok and sand dune, by Jill Sneesby from South Africa. First prize, 'Wild Places'.

Oryx Vol 21 No 1, January 1987 


\section{Society pages}

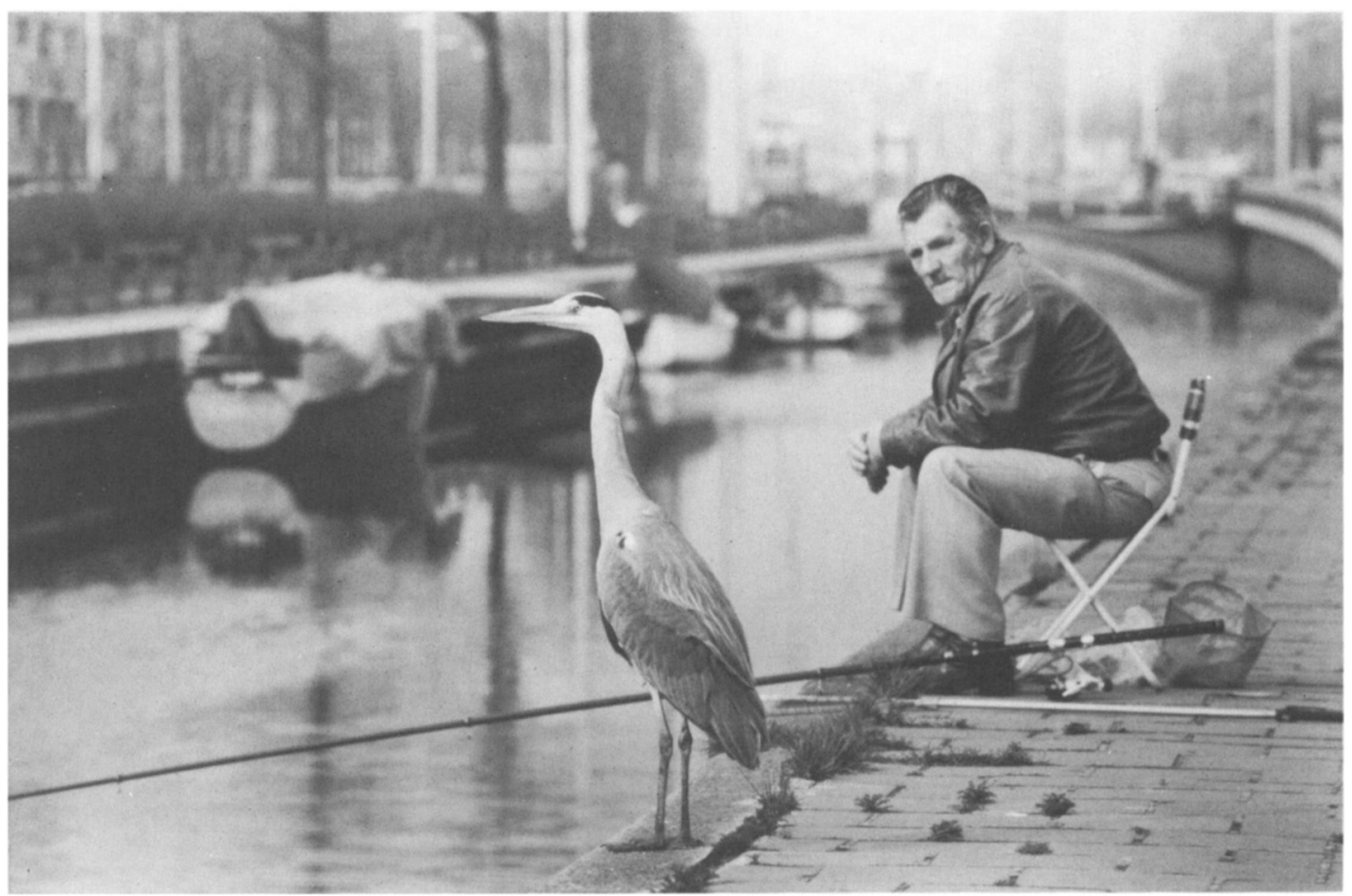

Fisherman with heron, by Angelo Gandolfi from Italy. First prize, 'Urban Wildlife'.

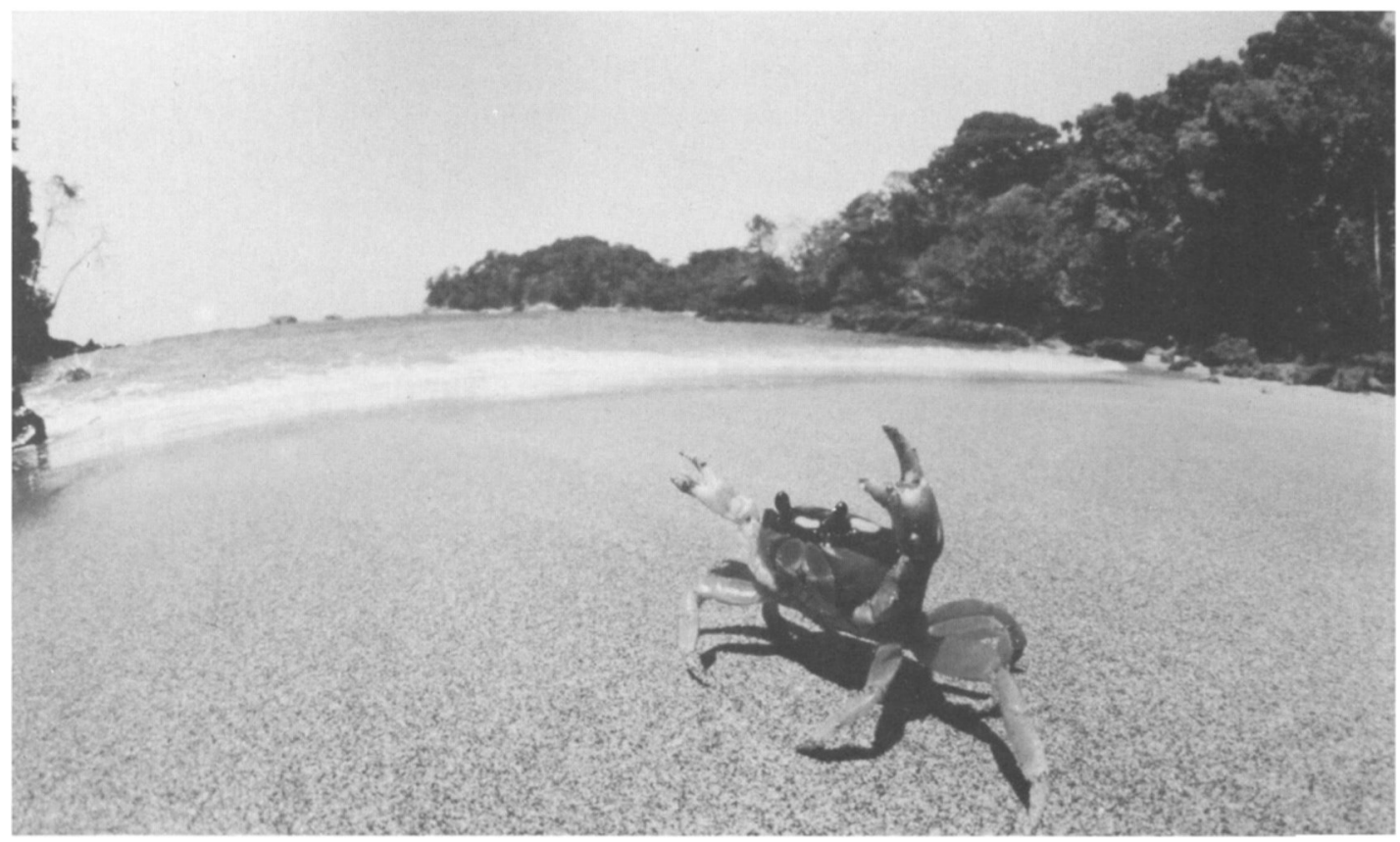

Crab on a beach, by Konrad Wothe from West Germany. First prize, 'Animal Behaviour —other animals'. 


\section{Society pages}

\section{Donovan Rosevear 1900-1986}

Donovan Reynold Rosevear CBE, who died on 17 January 1986, was born in 1900 . He was educated at Bedford School and at Christ's College, Cambridge, where he took the Mechanical Science Tripos and a Diploma in Forestry.

In 1924 he joined the Nigerian Forest Service, becoming Inspector General in 1951. He was a member of the Council of the Fauna Preservation Society (now the FFPS), a Fellow of the Linnean Society and of the Zoological Society of London (ZSL). In 1971 he received the Stamford Raffles Award of the ZSL in recognition of his contribution to the knowledge of West African mammals, and, in 1978, the H. H. Bloomer Award of the Linnean Society. He was a founding father of the Nigerian Field Society and Associate Editor of The Nigerian Field.

On becoming an Honorary Associate of the British Museum (Natural History) in 1955, he worked on a definitive account of West African mammals. Three volumes were published: The Bats of West Africa (1965), The Rodents of West Africa (1969), and The Camivores of West Africa (1974). His scientific work is of considerable importance and, in addition to these major works, includes a general booklet Nigerian Mammals (1951), The Rodents of Nigeria (in The Nigerian Field, 1949, 1950), and A Checklist and Atlas of Nigerian Mammals with a Foreward on Vegetation (1953). Shorter papers reviewed the classification of the smaller members of the African part of the bat genus Eptesicus, the West African forms of the squirrels Heliosciurus, and the squirrel genus Funisciurus. He also carried out a study of the rats of the subgenus Hylomyscus in West Africa.

He was a major contributor to West African zoology, his approach combining traditional taxonomy and a wide knowledge of habitats and ecology. His work was aimed at widening the understanding of a broad band of users, from the layman to the university zoologist or the professional mammalogist. He combined both practical and academic skills with scholarly and lucid writing.

J. E. Hill, British Museum (Natural History) 66

\section{Bird migration in China}

The area around Beidaihe, in Hebei Province, China, is an excellent place for studying bird migration. A narrow coastal plain flanked by mountains acts as a funnel for many of the birds whose migration routes are believed to cross there, and many of the species involved are rare. Between 1942 and 1945 a Danish scientist, Axel Hemmingsen, made an extensive study of the birds that pass through on migration, but after that little work was done on bird migration in China. In 1985 an expedition from Cambridge University set out to survey the spring migration at Beidaihe using Hemmingsen's study as a basis, and with the objective of producing data that could be of value in present and future assessments of population changes.

The report of the expedition, which the FFPS helped to fund, has just been published. Just under half of the 133 pages are devoted to the detailed observations of each of the 285 species recorded during the survey and, where possible, indications are given of each species's status, abundance and change in abundance since Hemmingsen's time. It was heartening to discover that the populations of most of the species seem to have changed little despite the drastic environmental changes that have taken place in China over the past four decades. The records include totals of 244 red-crowned cranes Grus japonensis (half of China's wintering population), 652 Siberian cranes Grus leucogeranus (40 per cent of the world's population), 132 great bustards Otis tarda, and two sightings of a swift that may be new to science.

There are accounts of changes in habitats since 1945 and of the effects of weather on migration. The results of a survey conducted at bird markets in Beijing, Qinhuangdua and Chengdu are given and the hazards facing migrant birds at Beidaihe are described. A follow-up study of autumn migration was planned for autumn 1986 , and the British and Chinese ornithologists who were cooperating in the venture were to assess the possibilities for establishing Beidaihe as a centre for the study of bird migration and for the promotion of conservation.

The Report on the Cambridge Omithological Expedition to China 1985 is available from Oryx Vol 21 No 1, January 1987 


\section{Society pages}

Sebastian Anstruther, 77a Princess Victoria Street, Clifton, Bristol BS8 4DD, UK, for $£ 8.50$. Please add $£ 1.40$ for postage in the UK, $£ 1.80$ for surface mail overseas, or $£ 4.00$ for air mail. Cheques should be made payable to CUETC re Cambridge Ornithological Expedition to China.

\section{Oryx 100\% Fund Grants}

At its meeting on 17 September 1986, the FFPS Council approved the following grants:

$\mathbf{f 6 0 0}$ to John Leefe OBE (Oakham. UK) for the development of the Balcad Nature Reserve. Somalia.

$£ 500$ to the ICBP World Working Group on Birds of Prey for a Survey of the Madagascar serpent eagle. This bird is possibly extinct. but may still survive in remote forest areas. Rediscovery of the eagle would help to bring pressure on the Madagascar Government to preserve its habitat.

$\mathfrak{\$ 5 0 0}$ to Sabina Knees (Kew. UK) for an expedition to Madagascar to assess the status of endemic succulents in habitat and trade.

$£ 400$ to Dr Quentin Cronk (Cambridge, UK) for his St Helena Flora and Conservation Project. This is a follow-up to the work initiated by the Royal Botanic Gardens, Kew, and the FFPS in 1983 both to ensure a wide genetic base for propagated material, and to complete the "Flora of St Helena', the first since 1875.

In addition, the FFPS has acquired two slide projectors, which are destined for Uganda for use at the forthcoming International Symposium on African Wildlife being organized by Dr Eric Edroma.

\section{FFPS New Council Members and Vice-Presidents}

At the FFPS Annual General Meeting on 10 September 1986 the following Council members retired, having completed their four-year term: Brian Jackman, Clive Jermy, Stuart Johnstone,
Jonathan Kingdon and the Hon. Vincent Weir. The following new Council members were elected: Dr Keith Banister. Stephen BanklerJukes. Lord Birkett. Dr Lee Durrell and Sue Runyard. Two new Vice-Presidents were also elected: Dr Gerard A. Bertrand and Gerald Durrell.

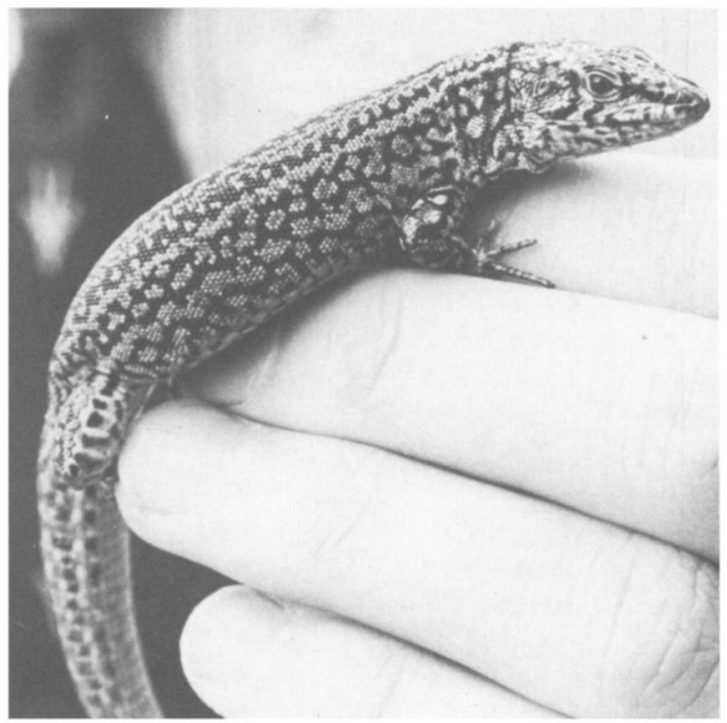

One of the 90 smuggled Ibiza wall lizards, photographed before being flown back to Ibiza (Michael Lyster, London Zoo).

\section{Lizards flown home}

Last October the FFPS came to the rescue of 90 Ibiza wall lizards Podarcis pityusensis, which had been taken illegally from Ibiza and offshore islands, where they are locally threatened. They were the survivors of a total of 500 discovered by HM Customs and Excise officers in a suitcase at Stansted Airport in the UK. While Colchester Zoo looked after them, the FFPS made arrangements for them to be sent to a wildlife sanctuary in Ibiza where they were put in the care of the Societas Europeae Herpetologica.

\section{Bats for an afternoon}

'Bats for an afternoon', organized by the FFPS, was held at the Queen Elizabeth Hall in London on 11 October 1986. Jeremy Cherfas introduced the afternoon's entertainment, which consisted of Tony Hutson, Bob Stebbings and David Pye 


\section{Society pages}

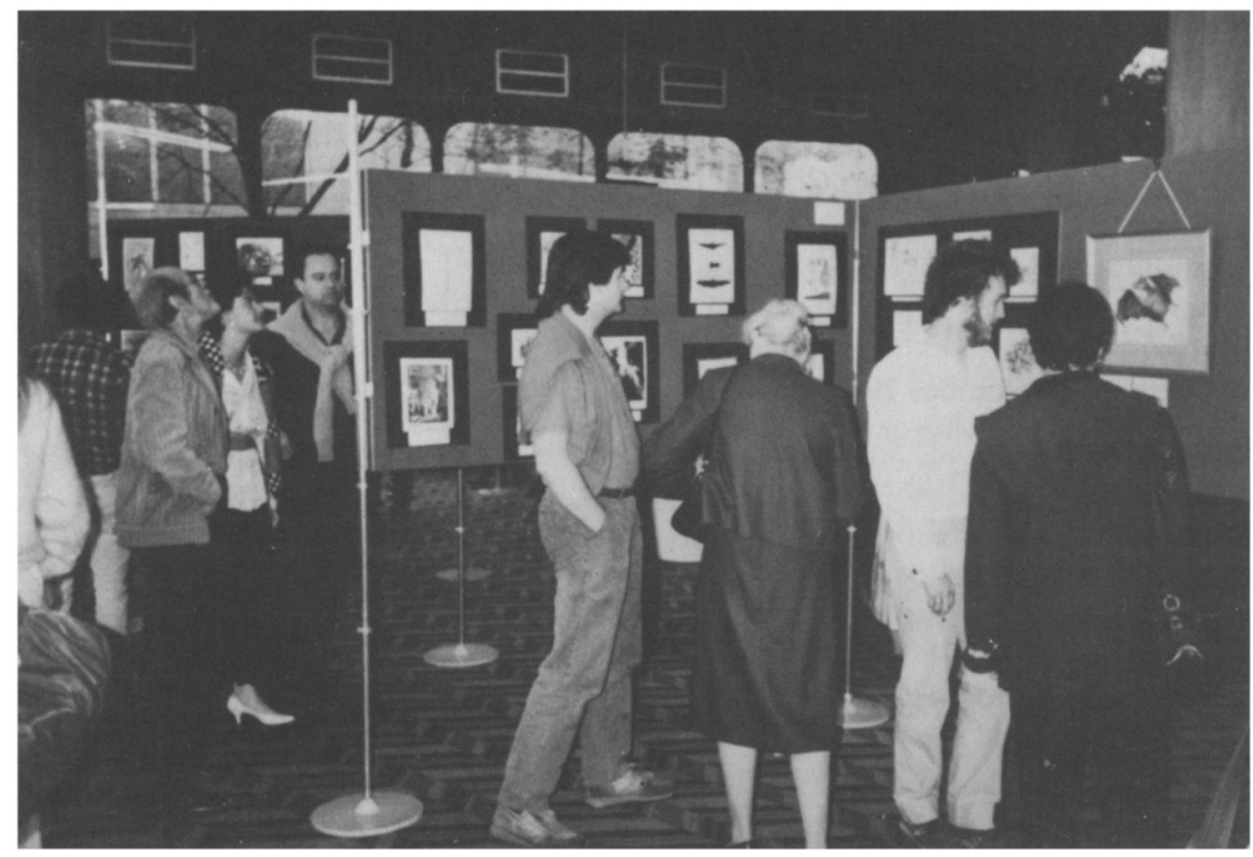

Some of the 500 people who attended 'Bats for an Aftemoon' studying the exhibition in the foyer of the Queen Elizabeth Hall in London. It was probably the largest collection of bat art and ephemera ever displayed (Tim Parmenter).

talking on various aspects of bat conservation and behaviour. Frank Thornton reading a selection of poetry and prose about bats, and a compilation of bats on film from the $\mathrm{BBC}$ archives. More than 500 people attended this successful event. and before and after the show were able to enjoy what was probably the largest exhibition to date of bats in art and culture.

\section{Loggerhead lecture}

Mrs Lily Veniselos, member of the Governing Council of the Hellenic Society for the Protection of Nature, will give an illustrated lecture on Loggerhead Turtles at $6.30 \mathrm{pm}$ on Tuesday 24 February 1987 at the Royal Geographical Society's Lecture Theatre (entrance in Exhibition Road, London, SW7). It will be introduced by Ian MacPhail, European Co-ordinator of the International Fund for Animal Welfare. Tickets, which cost $£ 3$ and include a glass of wine, can be obtained from the Anglo Hellenic League, Room 1B, Chelsea College, Manresa Road, London SW3 6LX. Telephone 01-351-6913. 68

\section{Members' meetings}

London meetings

Please see insert in this issue of Oryx.

Herpetofana Recorders'/Workers' Seminar

This Seminar will be held in London on 31 January and 1 February 1987. For further details please see insert in this issue of Oryx.

\section{Bristol and the West of England Group}

Thursday 26 February 1987: A Badger Evening with Dr Ernest Neal, at Bristol Zoo (College Road entrance) at $7.30 \mathrm{pm}$. Tickets cost $£ 3$ and include a wine and cheese buffet.

\section{North-West Group}

Friday 9 January 1987: An Evening of Madagascan Wildlife.

Friday 20 February 1987: Ian Redmond will talk on Underground Elephants.

Both meetings will be held at Chester Zoo. Tickets cost $£ 3.50$ and include a buffet supper. Full details are available from Nick Ellerton, telephone 0244380280.

Oryx Vol 21 No 1, January 1987 